\title{
KRITERIJI KVALITETE BILJNOG MATERIJALA I ETERIČNOG ULJA PRIMORSKOG SMILJA (HELICHRYSUM ITALICUM (ROTH.) G. DON)
}

\author{
Martina Peršić \\ Dr. sc., asistent, Veleučilište u Rijeci, Vukovarska 58, 51000 Rijeka, Hrvatska; \\ e-mail:martina.persic@bf.uni-lj.si \\ Karla Leko
}

Bacc. ing. agr., studentica, Veleučilište u Rijeci, Vukovarska 58, 51000 Rijeka, Hrvatska; e-mail:karlaaleko@gmail.com

Slavica Dudaš

Dr. sc., docent, Veleučilište u Rijeci, Vukovarska 58, 51000 Rijeka, Hrvatska; e-mail: sdudas@veleri.hr

\section{SAŽETAK}

Primorsko smilje (Helichrysum italicum (Roth.) G. Don) kserofitna je biljna vrsta prirodno prisutna u divljoj populaciji na području Mediterana, na krševitim i sušnim terenima. Još od davnina smilje je poznato kao "biljka koja ne vene" i veoma je cijenjeno zbog svoje široke primjene u narodnoj medicini. Antimikrobno, antivirusno, protuupalno, antioksidativno, regenerativno, insekticidno i repelentno djelovanje eteričnog ulja i hidrolata tema je brojnih istraživanja posljednjeg desetljeća. Upravo kemijski sastav eteričnog ulja i karakteristike biljnog materijala imaju direktan utjecaj na cijenu otkupa smilja. $\mathrm{U}$ istraživanju je provedeno anketiranje proizvođača i otkupljivača smilja i prikupljene informacije o kriterijima kvalitete biljnog materijala i eteričnog ulja smilja. Prikupljeni podaci pokazali su da su osnovni kriteriji kvalitete biljnog materijala kontrolirani uvjeti uzgoja, a glavni parametri kvalitete eteričnog ulja kemijski sastav, odnosno udio $\alpha$-pinena i neril acetata.

Ključne riječi: destilacija, hidrolat, otkup

\section{UVOD}

Smilje je cvatući grm žutih cvjetova i karakteristična mirisa koji raste kao aromatična višegodišnja biljka na osunčanim obalnim područjima. Prirodna populacija obuhvaća više od 600 različitih vrsta iz roda Helichrysum, od kojih je na mediteranskom području prisutno 25 (Morone-Fortunato et al., 2010). Od toga su na obalnom području Jadrana najčešće H. italicum (Roth) G. Don ssp. italicum i 
H. italicum ssp. microphyllum (Willd.) Nyman (Viegas et al., 2013). Karakteristika ovog roda izrazita je heterogenost u habitusu, listovima i cvjetovima (Maggio et al., 2016). Smilje se upotrebljava u tradicionalnoj medicini, najčešće u obliku infuzije, kao dezinficijens, te u ublažavanju simptoma prehlade i glavobolje (Benelli et al., 2018). Osim svoje dekorativne vrijednosti, primorsko smilje (Helichrysum italicum) ima dokazana i mnoga utilitarna svojstva. I nadzemnog dijela biljke (herbe) proizvode se eterično ulje i hidrolat koji su zbog svojih protuupalnih, antivirusnih $\mathrm{i}$ antimikrobnih svojstva zanimljivi farmaceutskoj industriji (Guinoiseau et al., 2013).

U posljednjem desetljeću javio se značajan interes za komercijalni uzgoj smilja, proizašao iz visoke cijene otkupa biljnog materijala i eteričnog ulja. S obzirom na to da se može uzgajati na kršovitim i teže obradivim kamenim tlima, smilje je postalo poželjna i popularna vrsta kod mnogih uzgajivača. Ipak, posljednjih godina cijena otkupa značajno je pala zbog hiperprodukcije i velikih intenzivnih nasada na području Hrvatske i Bosne i Hercegovine.

Cilj uzgoja smilja je nadzemni dio biljke, prvenstveno cvijet iz kojega se preradom izdvaja eterično ulje. Najčešće se eterično ulje dobiva hidrodestilacijom svježe biljne mase. $U$ procesu destilacije cvjetova smilja kao nusproizvod nastaje hidrolat koji je zbog intenzivnog i ugodnog mirisa cijenjen u kozmetičkoj industriji.

Jedan od glavnih parametara kvalitete eteričnog ulja i hidrolata je njihov biokemijski sastav. Sadržaj tvari iz skupine monoterpena, seskviterpena i terpenskih alkohola te estera, aldehida i ketona određuju kvalitetu eteričnog ulja, dok sastav fenolnih tvari određuje kvalitetu hidrolata smilja. Fenolni profil hidrolata predstavljaju većinom flavonoidi i hidroksicimetne kiseline koje imaju izrazit antioksidativni potencijal (Taglialatela-Scafati et al., 2012).

Kemotip eteričnog ulja ovisan je u prvom redu o anatomskom i morfološkom polimorfizmu, ali i o mnogim agroekološkim čimbenicima kao što su tlo, osunčanost, klima, nadmorska visina, kao i o vremenu berbe i načinu prerade (Angioni et al., 2003; Morone-Fortunato et al., 2010). Kemotip eteričnog ulja specifičan je za svaku podvrstu, a rezultat je karakterističnog enzimskog kompleksa koji determinira biosintezni put sekundarnih metabolita odgovornih za medicinska i kozmetička svojstva. Mnoga istraživanja potvrdila su razliku između podvrsta u kvalitativnim i/ili kvantitativnim varijacijama koje se mogu pripisati genotipu (Bianchini et al., 2003; Bianchini et al., 2001; Roussis et al., 2000; Tucker et al., 1997). Od ekoloških čimbenika najveći utjecaj na kemotip imaju vrsta tla i geografska lokacija (Bianchini et al., 2003).

Cilj ovog istraživanja bio je definiranje kriterija kvalitete eteričnog ulja smilja anketiranjem proizvođača, otkupljivača i prerađivača. Dodatno, cilj je istraživanja bio prikupiti podatke o željenim i neželjenim kemijskim komponentama koje utječu na cijenu otkupa biljnog materijala i eteričnog ulja smilja.

\section{METODOLOGIJA}

Sakupljanje podataka provedeno je slanjem upitnika na e-mail adrese te telefonskim anketiranjem proizvođača, otkupljivača i prerađivača smilja koji su evidentirani na internetskim stranicama i društvenim mrežama. Upit je poslan na 100 adresa ispitanika od kojih se odazvalo 20 osoba. 
Udio pojedinih anketiranih skupina bio je sljedeći: 23,0 \% uzgajivača smilja, 46,2 \% uzgajivača i prerađivača smilja, 7,7 \% uzgajivača, otkupljivača i prerađivača, $23,1 \%$ otkupljivača i prerađivača. Ispitivanje je provedeno u razdoblju od ožujka do travnja 2018. godine. Pitanja su bila usmjerena na dobivanje detaljnih informacija o definiranju kvalitete i postupka prerade smilja.

Upitnik je sadržavao sljedeća pitanja:

1) Tko su na Vašem području otkupljivači smilja?

2) Koja je cijena otkupa smilja, ovisno o tome radi li se o sviježem i/ili suhom materijalu?

3) Koji su kriteriji za otkup smilja?

4) Koju vrstu smilja otkupljujete, samoniklu ili iz uzgoja?

5) Što definira pojam kvalitete kod otkupa smilja?

6) Kako se ocjenjuje kvaliteta smilja pri otkupu?

7) Ako provodite destilaciju eteričnog ulja, koju aparaturu za destilaciju koristite (naziv poduzeća)?

8) Koliko traje destilacija eteričnog ulja?

9) Koji su proizvodi destilacije?

10) U čemu čuvate proizvode destilacije?

11) Koji su uvjeti čuvanja proizvoda destilacije?

12) Kako zbrinjavate ostatak biljnog materijala nakon destilacije?

13) Koja svojstva bi trebalo posjedovati eterično ulje smilja? Vizualno/senzorika/kemijski sastav?

14) kako ispitujete kvalitetu eteričnog ulja smilja?

15) Koji laboratorij koristite za ispitivanje sastojaka eteričnog ulja smilja?

16) Koji sastojci, prema Vašem mišljenju, definiraju kvalitetu eteričnog ulja smilja u pozitivnom i negativnom smislu?

\section{REZULTATI I RASPRAVA}

\section{1 Definiranje kriterija kvalitete biljnog materijala}

Rezultati ankete pokazali su da su otkupljivači smilja većinom vlasnici destilerija, ali značajan udio čine i inozemne tvrtke preko ugovorom vezanih kooperanta. Velik dio ispitanika smilje uzgaja s namjenom prerade u vlastitoj destileriji. Najmanji dio otkupljuju obiteljska poljoprivredna gospodarstva te ostali kupci. 
Cijena otkupa smilja značajno varira, ovisno o godini. Naime, 2016. godine cijena otkupa smilja bila je visokih $17 \mathrm{kn} / \mathrm{kg}$, što je mnoge poljoprivrednike motiviralo na podizanje nasada. U sljedećim godinama (2017. i 2018.) zbog zasićenja tržišta cijena je pala za više od tri puta.

Kao kriterije za otkup smilja ispitanici su naveli certificirani ekološki uzgoj (1), udaljenost od prometnica, vinograda i drugih intenzivnih nasada najmanje 1 kilometar (2), čista zelena masa smilja, bez primjesa drugog biljnog materijala i zemlje (3), svježe ubrani biljni materijal (4), dokaz o izvornosti smilja (5) te cijena (6). Kriteriji su navedeni prema udjelu ispitanika.

Razlog za certificirani ekološki uzgoj smilja kao parametar koji utječe na otkup je certificiranje krajnjeg proizvoda, čime se postiže značajno veća cijena u usporedbi s proizvodom dobivenim preradom konvencionalno uzgojenog smilja. Isto tako, blizina prometnica i intenzivnih nasada utječe na kvalitetu krajnjeg proizvoda, odnosno na sastav, čistoću te, posljedično, cijenu eteričnog ulja. Na sastav i kvalitetu eteričnog ulja imaju značajan utjecaj i primjese drugog biljnog materijala (npr. korova) koji mogu utjecati na prisutnost neželjenih toksičnih kemijskih spojeva u eteričnom ulju ili hidrolatu.

Definiranje pojma kvalitete smilja usko je vezano uz kriterije za otkup smilja. Iz odgovora anketiranih vidljivo je da uvjeti uzgoja moraju biti što sličniji uvjetima prirodnog staništa smilja. Takvi uvjeti obuhvaćaju mikrolokacije $s$ kamenitim tlom, velikom insolacijom i dužim sušnim razdobljima. Rezultat uzgoja smilja u stresnim uvjetima je veći sadržaj sekundarnih metabolita koji se u takvim uvjetima javljaju kao obrambeni mehanizam. Kao direktna posljedica je veći udio eteričnog ulja na kilogram biljnog materijala.

Često se, osim vizualnog pregleda biljaka, prije otkupa obavlja probna destilacija i analiza kemotipa. Određivanje preciznog kemijskog sastava eteričnog ulja, odnosno kemotipa eteričnog ulja, ovisi o primjeni i razlikuje se među farmaceutskom, aromaterapijskom ili kozmetičkom namjenom. Nakon berbe, svježa biljna masa se mora destilirati u najkraćem mogućem roku, kako bi se dobilo eterično ulje najviše kvalitete. Nakon berbe, prilikom manipulacije biljnim materijalom, dolazi do narušavanja strukture staničnog tkiva, zbog čega dolazi do razgradnje, oksidacije i hlapljenja bioaktivnih tvari koje čine eterično ulje.

Još jedan od parametara koji otkupljivači navode kao glavni kriterij za otkup je dokaz o izvornosti smilja. Glavni razlog je zakonski propisana zabrana sakupljanja smilja iz samonikle populacije na hrvatskim otocima. To je i jedan od razloga zbog kojeg čak 82 \% otkupljenog smilja dolazi iz organiziranog plantažnog uzgoja i tek $18 \%$ iz prirodne populacije.

\section{2 Postupak destilacije i uvjeti skladištenja eteričnog ulja i hidrolata}

Prema prikupljenim podacima destilacija se najčešće odvija u klasičnim bakrenim parnim kotlovima, iako se spominju kotlovi od nehrđajućeg čelika (inoksa) različitih zapremina. U ciklusu destilacije koji u prosjeku traje 1:40 h, kao proizvodi dobivaju se eterično ulje i hidrolat. Ispitanici su naveli nekoliko vrsta ambalaža za čuvanje ulja, kao što su: ambalaža od nehrđajućeg čelika (inoksa), boce od tamnog stakla i aluminijska ambalaža, dok se hidrolat skladišti u plastičnim bocama na kraće vrijeme. Zapremina staklene ambalaže kreće se od 1 do $5 \mathrm{~L}$, a aluminijskih spremnika od 1 do 
100 L. Kao uvjeti skladištenja eteričnog ulja navedeni su tamni i suhi prostori s temperaturama do $22^{\circ} \mathrm{C}$. Ostatak biljnog materijala nakon destilacije u najvećoj mjeri zbrinjava se preradom u humus, odlaganjem u prirodu ili preradom u pelete.

\section{3 Definiranje kvalitete eteričnog ulja}

Kao glavne poželjne karakteristike eteričnog ulja smilja ispitanici su naveli zlatnožutu boju (1), prepoznatljiv intenzivan miris (2), bistroću (3), udio $\alpha$-pinena manji od $25 \%$ (4) te udio neril acetata veći od $5 \%$ (5). Karakteristike ulja razlikuju se ovisno o namjeni. Ispitivanje sastava ulja metodom plinske kromatografije izvode akreditirani agromediteranski zavodi, instituti, agronomski fakulteti, fakulteti kemijske tehnologije i privatni laboratoriji. Kao pozitivne komponente eteričnog ulja prema rezultatima anketa izdvojeni su neril acetat, $\gamma$-kurkumen, italidoni te $\beta$-selinen. TaglialatelaScafati et al. (2012) analizirali su pojedine komponente eteričnog ulja smilja te neril acletat izdvojili kao glavnu aktivnu tvar koja ima analgetički učinak.

Kao negativne komponente ispitanici su naveli $\alpha$-pinen, limonen, linalol. Jensen et al. (2001) dokazali su da monoterpeni zastupljeni u visokim koncentracijama imaju iritabilan učinak na dišne puteve.

\section{ZAKLJUČAK}

Dobiveni podaci pridonose definiranju kriterija kvalitete biljnog materijala i eteričnog ulja smilja na tržištu. Sastav eteričnog ulja u velikoj mjeri ovisi o uvjetima uzgoja smilja, a kempotipom je određena ne samo namjena ulja, već i njegova kvaliteta i cijena. Utvrdili smo da su pri otkupu biljnog materijala najvažniji parametri kvalitete uvjeti uzgoja, dok je pri eteričnom ulju kvaliteta definirana u prvom redu sadržajem i omjerom $\alpha$-pinena i neril acetata.

\section{LITERATURA}

Angioni, A. et al. (2003) Chemical composition, plant genetic differences, and antifungal activity of the essential oil of Helichrysum italicum G. Don ssp. microphyllum (Willd) Nym. Journal of agricultural and food chemistry, 51(4), p. 1030-1034. https://doi.org/10.1021/jf025940c

Benelli, G. et al. (2018) Chemical composition and insecticidal activity of the essential oil from Helichrysum faradifani endemic to Madagascar. Natural product research, 32(14), p. 1690-1698. https://doi.org/10.1080/14786419.2017.1 396590

Bianchini, A. et al. (2001) Composition of Helichrysum italicum (Roth) G. Don fil. subsp. italicum essential oils from Corsica (France). Flavour and fragrance journal, 16(1), p. 30-34. https://doi.org/10.1002/1099-1026(200101/02)16:1<30::AIDFFJ941>3.0.CO;2-F

Bianchini, A. et al. (2003) A comparative study of volatile constituents of two Helichrysum italicum (Roth) Guss. Don Fil subspecies growing in Corsica (France), Tuscany and Sardinia (Italy). Flavour and fragrance journal, 18(6), p. $487-491$. https://doi.org/10.1002/ff. 1231

Guinoiseau, E. et al. (2013) Biological properties and resistance reversal effect of Helichrysum italicum (Roth) G. Don. Microbial pathogens and strategies for combating them: science, technology and education, 2, p. 1073-1080. 
M. Peršić, K. Leko, S. Dudaš: Kriteriji kvalitete biljnog materijala i eteričnog ulja primorskog smilja... Zbornik Veleučilišta u Rijeci, Vol. 7 (2019), No. 1, pp. 425-431

Jensen, L. K. et al. (2001) Health evaluation of volatile organic compound (VOC) emissions from wood and woodbased materials. Archives of Environmental Health: An International Journal, 56(5), p. 419-432. https://doi. org/10.1080/00039890109604477

Maggio, A. et al. (2016) Contribution to a Taxonomic Revision of the Sicilian Helichrysum Taxa by PCA Analysis of Their Essential-Oil Compositions. Chemistry \& biodiversity, 13(2), 151-159. https://doi.org/10.1002/cbdv.201500052

Morone-Fortunato, I. et al. (2010) Essential oils, genetic relationships and in vitro establishment of Helichrysum italicum (Roth) G. Don ssp. italicum from wild Mediterranean germplasm. Industrial crops and products, 32(3), p. 639-649. https://doi.org/10.1016/j.indcrop.2010.07.023

Roussis, V. et al. (2000) Volatile constituents of four Helichrysum species growing in Greece. Biochemical Systematics and Ecology, 28(2), p. 163-175. https://doi.org/10.1016/S0305-1978(99)00046-0

Taglialatela-Scafati, O. et al. (2012) Antimicrobial phenolics and unusual glycerides from Helichrysum italicum subsp. microphyllum. Journal of natural products, 76(3), p. 346-353. https://doi.org/10.1021/np3007149

Tucker, A. O. et al. (1997) Volatile leaf oil of the curry plant [Helichrysum italicum (Roth) G. Don subsp. italicum] and dwarf curry plant [subsp. microphyllum (Willd.) Nyman] in the North American herb trade. Journal of Essential Oil Research, 9(5), p. 583-585. https://doi.org/10.1080/10412905.1997.9700781

Viegas, D. A. et al. (2014) “Helichrysum italicum: From traditional use to scientific data." Journal of ethnopharmacology, 151(1), p. -65. https://doi.org/10.1016/j.jep.2013.11.005 


\title{
CRITERIA FOR THE QUALITY OF PLANT MATERIAL AND ESSENTIAL OIL OF IMMORTELLE (HELICHRYSUM ITALICUM (ROTH.) G. DON)
}

\author{
Martina Peršić
}

PhD, Assistant, Polytechnic of Rijeka, Vukovarska 58, 51000 Rijeka, Croatia; e-mail:martina.persic@bf.uni-lj.si

\section{Karla Leko}

BSc, Student, Polytechnic of Rijeka, Vukovarska 58, 51000 Rijeka, Croatia; e-mail:karlaaleko@gmail.com

\section{Slavica Dudaš}

PhD, Assistant Professor, Polytechnic of Rijeka, Vukovarska 58, 51000 Rijeka, Croatia; e-mail: sdudas@veleri.hr

Immortelle (Helichrysum italicum) is a xerophytic plant species naturally present in the wild population of Mediterranean on karst and dry terrains. Since ancient times, the immortelle has been known as a "non-vein plant" and is highly valued due to its wide application in folk medicine. Antimicrobial, antiviral, anti-inflammatory, antioxidative, regenerative, insecticidal and repellent properties of essential oil and hydrolates are a frequent subject of recent research. The chemical composition of the essential oil and characteristics of plant material have a direct effect on market price. This research was conducted by a survey of producers and buyers of immortelle plant material and essential oil with the aim to gather information on the quality criteria of plant material and essential oil. The collected data showed that the basic criteria for quality determination of plant material are controlled growing conditions and the main parameters affecting the price of the essential oil are chemical composition, i.e. the content and ratio of $\alpha$-pinene and neryl acetate.

Key words: distillation, hydrolate, market price 